\title{
Should LSP Dictionaries also Include Professional Jargon and Slang?*
}

Rosemarie Gläser, Foreign Language Centre; University of Leipzig, Leipzig, Germany

\begin{abstract}
The paper discusses the question whether an LSP dictionary should take the sociolinguistic stratification of the entire speech community in a particular domain of activity into consideration, and as a consequence, also encompass vocabulary on the lower stylistic levels, such as professional jargon and occupational slang in addition to technical terminology and nomenclature. The author's contention is that by including such vocabulary, an LSP dictionary will be more comprehensive and closer to the communicative reality. Moreover, it will meet the more specific requirements of translators and interpreters. To substantiate this claim, the author examined two monolingual English dictionaries and five bilingual English-German (German-English) dictionaries published between 1973 and 2000, which have successfully incorporated professional jargon and slang. The subject areas covered range fróm law, economics, accountancy and business administration to geology, geophysics, geotectonics, and to automotive engineering. Some lexicographers have used style markers or usage labels (such as informal, collaquial, slang, vulgar, umgangssprachlich, formlich, gehoben, finance, matoring, press) for vocabulary bearing stylistic or expressive connotations. As a rule, these style markers have only been given to key words of the source language so that they may be inferred for the target language equivalent. Ideally, as one dictionary author has proved, style markers should also be attached to target language equivalents. However, an LSP lexicographer must be aware of the fact that informal and slang words may be short-lived and be substituted by other colloquial and colourful words from oral communication - and that slang words may gradually lose their connotations and become stylistically neutral words and even terms.
\end{abstract}

Keywords: LSP DICTIONARY, TECHNICAL TERM, ITEM OF NOMENCLATURE, TRIVIAL (POPULAR) NAME, PROFESSIONAL JARGON, OCCUPATIONAL SLANG, TRADE NAME, CONNOTATION, STYLISTIC LEVEL/LEVEL OF STYLE, STYLE MARKER, USAGE LABEL, MONOLINGUAL/BILINGUAL DICTIONARY, SOCIOLINGUISTIC STRATIFICATION OF THE SPEECH COMMUNITY.

\section{Zusammenfassung: Sollen Fachwörterbücher auch Berufsjargon und Slang} einbeziehen? Der Artikel erörtert das Problem, ob ein Fachwörterbuch auch die soziolinguistische Schichtung der gesamten Kommunikationsgemeinschaft eines Fachgebietes berücksichtigen

* This paper was presented at the Fifth Intemational Conference of the African Association for Lexicography, held at the University of Stellenbosch, Stellenbosch, 3-5 July 2000. 
und folglich neben der Terminologie und Nomenklatur auch den Wortschatz der unteren Stilebenen, wie Berufsjargon und -slang, einbeziehen sollte. Die Autorin geht von der These aus, daß durch die Einbeziehung dieses Wortschatzes ein Fachwörterbuch an Umfang gewinnt, der kommunikativen Wirklichkeit stärker angenähert ist und speziellen Anforderungen der Übersetzer und Dolmetscher eher gerecht wird. Zur Stützung dieser These hat die Autorin zwei einsprachige englische und fünf zweisprachige englisch-deutsche (deutsch-englische) Fachwörterbücher untersucht, die zwischen 1973 und 2000 erschienen sind und den Vorteil haben, daß sie auch Berufsjargon und -slang berücksichtigen. Dje hier vertretenen Fachgebiete reichen von der Rechts-, Wirtschafts- und Börsensprache zur Sprache der Geowissenschaften und der Kraftfahrzeugtechnik. Einige Lexikographen verwenden Stilmarkjerungen und Sachgebietsindikatoren (z.B. informal, colloquial, slang, vulgar, umgangssprachlich, formlich, gehoben, finance, motoring, press) für Wörter mit stilistischen oder expressiven Konnotationen. In der Regel sind diese Stilmarkienungen nur bei den ausgangssprachlichen Wörtern verzeichnet, so daß sie bei dem zielsprachlichen Äquivalent erschlossen werden müssen. Im Idealfalle sollten die Stilmarkierungen auch bei den zielsprachlichen Äquivalenten angegeben werden, wofür einer der Wörterbuchautoren den Beweis geliefert hat. Jedoch muß sich der Fachwörterbuchautor stets der Tatsache bewußt sein, daß Jargon- und Slangwörter kurzlebig sein und durch andere umgangssprachliche und plastische Wörter aus dem mündlichen Sprachgebrauch ersetzt werden können - ebenso wie Slangwörter allmählich ihre Konnotationen verlieren, stilistisch neutrale Bezeichnungen und sogar Termini werden können.

Stichwörter: FACHWÖRTERBUCH, TERMINUS, NOMENKLATURZEICHEN, TRIVIALNAME, BERUFSJARGONISMEN, BERUFSSLANG, WARENNAME, KONNOTATION, STILEBENE, STILMARKIERUNG, SACHGEBIETSINDIKATOR, EINSPRACHIGES / ZWEISPRACHIGES WORTERBUCH, SOZIOLINGUISTISCHE SCHICHTUNG DER KOMMUNIKATIONSGEMEINSCHAFT.

\section{Introduction}

In this paper I will discuss the question to what extent a specialist dictionary should reflect the social stratification of an LSP in such a way that it also includes words and phrases from the lower stylistic levels. This general problem touches monolingual and bilingual dictionaries alike, but its solution depends on a number of presuppositions. The first is the individual lexicographer's theoretical understanding of the range of a technical vocabulary and of the social differentiation of LSP communication. In other words, the option is

- whether technical vocabulary is limited to terminology and nomenclature as lexical units of written communication that have a clear-cut meaning and are stylistically neutral, or

- whether technical vocabulary is extended to words and phrases of spoken discourse in which they occur as professional jargon and occupational slang, as popular names for items of nomenclature, and also as trade names. 
The lexicographer's primary decision on the range of vocabulary covered in an LSP dictionary will be influenced by a number of factors. These include

(a) the composition of the word-stock in a particular domain,

(b) the intention of the LSP dictionary: whether it will describe and explain current usage or prescribe and stipulate preferable vocabulary, and

(c) the target group of the prospective dictionary users, which may range from specialists on a high theoretical, academic level to technicians, laboratory staff, and factory workers - and to people in the applied field in the broadest sense.

My paper is based on the assumption that the inclusion of technical jargon and slang in an LSP dictionary will always be an asset to such a reference book and provide an additional benefit to the user, especially to translators and interpreters.

As a rule, professional jargon and slang are typical of oral communication, but they may occasionally enter written texts, especially in journalism. They are colourful metaphorical or metonymical expressions. As they spring up in everyday practical work, their appearance may be drastic and "shirt-sleeved". In this respect such informal or slangy LSP words confirm and underpin an old dictum, a "winged word" about slang which reads: "Slang is language that rolls up its sleeves, spits in its hands and sets to work."

\section{The stratification of LSP vocabulary}

The specialist vocabulary used in a particular domain of social activity is not monolithic, but structured according to

(a) the level of abstraction (and cognition) which determines the meaning of technical terms,

(b) the degree of the communicative partner's expertise, and

(c) the character of work done by those people who work in a special domain, ranging from research and development, to designing and planning, and finally to the sphere of production and distribution.

In terms of a vertical stratification of LSP (cf. Sager, Dungworth and McDonald 1980 ), its vocabulary includes

\section{(a) technical terms}

As a rule, technical terms designate a defined concept. Thus, they have a nominating and a defining function. They are expected to be precise, unequivocal, unemotional, stylistically neutral, without evaluative connotations, and suitable for patterns of word-formation. 
(b) items of nomenclature

Nomenclatures are taxonomies and are understood as a specific field of terminology. These lexical units only have a nominating and classifying, but no defining function. They designate individual objects which as a whole constitute a scientific system, for example in biology (the Linnaean system of plants and animals), in chemistry (the periodical system of elements, or the IUPAC nomenclature of compounds), in medicine (the nomenclature of bones, muscles, nerves, glands, inner organs, diseases and symptoms, etc.). The individual items of nomenclature cannot be named at random, but must follow international word-formation rules.

\section{(c) trivial (popular) names}

These are colloquial synonyms of systematic names and are circulating in everyday language. Moreover, they are much older than systematic names, may count as prescientific, and designate minerals, plants, animals, diseases, chiefly in the spoken language. Trivial names are often listed in LSP dictionaries, depending on the lexicographer's broader or narrower concept of technical discourse. They are always included in traditional encyclopedic LGP dictionaries, such as Langenscheidts Grosswörterbuch der englischen und deutschen Sprache, Der kleine Muret-Sanders.

(d) jargon words (professional jargon, indoor jargon) and slang words These informal words are typical of oral LSP communication in an everyday working environment; they do not designate a concept classified in a system or coined according to international patterns. Professional jargon is down-toearth, drastic and shirt-sleeved. It may include colourful idiomatic expressions.

\section{(e) trade names}

Names for commodities and services are arbitrary and often short-lived. They label specific products in the sphere of production and consumption and have no conceptual essence. Trade names or trade marks are in fact proper names. A number of them are registered trademarks and therefore an essential part of LSP vocabulary.

\section{Materials and Method}

My paper is based on a linguistic analysis of two monolingual and five bilingual LSP dictionaries whose authors have successfully incorporated technical jargon and slang and, with few exceptions, have also used style markers. These include the labels informal, colloquial, slang, vulgar, rare, and obsolete. The subject areas covered in this comparative survey range from law (Peter $\mathrm{H}$. Collin; Alfred Romain, Hans Anton Bader and B. Sharon Byrd); economics, accountancy business (Hermann Fink; Theo van Bernem; Wilhelm Schäfer) to 
geophysics, geotechnology and geotectonics (H.-J. Behr and W. Bachmann), and to automotive engineering (Peter Axel Schmitt).

\section{Corpus Analysis}

\subsection{Monolingual dictionaries}

\subsubsection{Peter H. Collin (1994 ${ }^{2}$ [1986]): Dictionary of Law.}

This dictionary contains about 7000 lexical items (classified as "terms") from the legal language. The dictionary implicitly mirrors the social, communicative composition and stratification of the community that constitutes the "legal profession". There are numerous Latin words and phrases on the formal stylistic level, such as audi et alteram partem ("hear the other side"), de jure - de facto ("by right - in fact"), casus belli ("case of war"), donatio mortis causa ("gift because of death"), abbreviations (c.o.d. = "cash on delivery"), French expressions like carte blanche, and words which the author has labelled as "informal". These are typical examples of professional jargon. To quote a few expressions:

graft - "corruption of officials", quickie - "divorce which is processed rapidly through the court by the use of the special procedure",

devil - "barrister to whom another barrister passes work because he is too busy",

dove - "person who prefers diplomacy and tries to achieve peace",

hawk - "person who believes in threatening the use of armed force as a means of settling problems between countries",

kangaroo - "system used when discussing a bill where some clauses are not discussed at all, but simply voted on, with the discussion then moving on to the next item; this is illustrated by the compound kangaroo court".

A remarkable feature of this dictionary is the listing of number of words classified as "(prison) slang". They are either simplex or compound lexemes, native (Germanic) words, and chiefly metaphors. They designate persons involved in criminal activities. Other words are related to things. Compare the following examples:

grass - "criminal who gives information to the police about other criminals",

bellman - "criminal who specialises in stopping alarm signals", cracksman - "criminal who specialises in breaking safes",

baron - "prisoner who has power over other prisoners because he sells tobacco and runs rackets in prison", 
dip - "pickpocket",

screw - "prison warder" (American English for "warden"),

bracelets - "handcuffs" (a metonymical expression).

The slang words in a legal dictionary are an essential supplement because they shed some light on down-to-earth communication among prisoners and indoor staff.

\subsubsection{Hermann Fink $\left(1999^{\circ}\right)$ : Econoterms. A Glossary of Economic Terms. With a Supplement EconoSlang}

Hermann Fink's glossary, which has become a household reference book for students, translators and subject specialists, includes an independent wordlist under the heading "EconoSlang". The author's justification for including this stratum of nonterminological words into his dictionary of economics and business administration is of particular sociolinguistic interest.

In the introduction (Fink 19996: 279) we read:

EconoSlang presents a collection of approximately 1300 colloquial terms and expressions typical of American business jargon frequently used in trade and industry and in the press.

Most of the entries are slang, indeed, some are considered vulgar or obscene. Other entries simply reflect the linguistic creativity of the American language - the tendency to play on words and use metaphorical, colourful, and often exaggerated expressions especially in business terminology ... Consequently, EconoSlang should be regarded as a guide reference tool and as an introduction to the typical American business jargon that economics students and others interested or working in the field of business and economics will eventually encounter.

Examples from the wordlist of EconoSlang confirm the reader's observation that most expressions have a figurative meaning. The vocabulary includes metaphorical simplex words, compounds and idiomatic phrases. Vulgar words are rather marginal cases.

Simplex words:

grease -"bribe",

cannibalize - "(to) use assets of one part of a company to support another", trafficking - "(to) deal in illegal merchandise (e.g. drugs)".

Compounds:

bullshit (vulgar) - "false or faulty information, nonsense", bellyache - "complaint" (e.g. the union has a bellyache), 
play-money - "money one can afford to lose; money used in games, foreign currencies (derogatory)".

Idiomatic phrases:

hot money - "stolen money",

to earmark (funds) - "(to) reserve funds for special uses",

to bust one's britches (vulgar) - "to work very hard" (britches is the American spelling of breeches),

to piss on (vulgar) - "attempt to damage the reputation of a co-worker".

On the whole, Hermann Fink's glossary is unrivalled in its scope of current vocabulary on the lower levels of style, which is, nevertheless, current usage of American journalists in economic reports.

\subsection{Bilingual Dictionaries}

4.2.1. Alfred Romain, Hans Anton Bader and B. Sharon Byrd (20005): Wörterbuch der Rechts- und Wirtschaftssprache. Teil 1. EnglischDeutsch.

In this English-German Dictionary of Law and Economics, the authors have included regional and social varieties of LSP use, such as specific German words used in Austria, Americanisms, on the one hand, and slang words, largely described as "Fachjargon", on the other. The following examples are most illustrative:

cop- (sl.) "Polizistt"

cop - (verb) (US sl.) "wegnehmen, stehlen, gewinnen"

cook - (verb) (sl.) "(Bilanz, Rechnung) verschleiem, fälschen"

lifer - (sl.) "Lebenslänglicher, zu 'lebenslänglich' Verurteilter, lebenslange Freiheitsstrafe".

4.2.2. Theodor van Bernem (19943): Wirtschaftsenglisch-Wörterbuch. Englisch-Deutsch. Deutsch-Englisch.

Although Van Bernem does not apply usage labels in his dictionary of business English, a considerable number of words and phrases are qualified as informal, colloquial or even slang by their German equivalents. In this respect, the dictionary user is offered word equivalents on the same level of style. This vocabulary includes new coinages from business journals and journalists' jargon which have not yet gained a wide circulation. For this reason, the author could in a number of cases only suggest the German equivalent of an English neologism 
as a context-sensitive translation. But the author was able to offer the German user an acceptable equivalent with approximate connotations and to trace business language in its making.

Another striking feature is that quite a number of the business expressions on the level of jargon or slang have negative conceptual associations and derogatory expressive connotations. They may be allocated to semantic fields related to persons, actions or situations. Many of them are animal metaphors.

Colloquial and slang expressions for persons are:

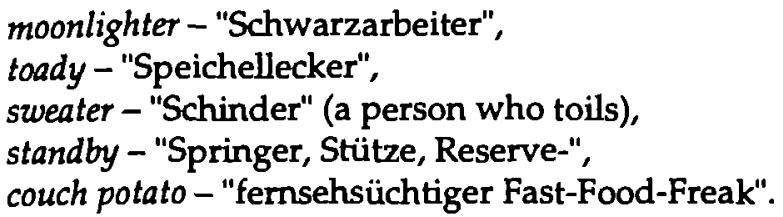

Compound nouns based on a metaphorical element may designate situations. The conceptual content of the expressions equally contains a negative value judgement. Examples are:

window dressing - "Bilanzverschleierung, Bilanzkosmetik", rat race - "Postenjägerei, harte Berufskonkurrenz",

sunset industry - "niedergehender, sinkender Wirtschaftszweig" (as opposed to sunrise ind ustry - "aufstrebender Wirtschaftszweig"), peanut economics - "wirtschaftliches Intrigenspiel".

Similar negative associations are connected with string compounds of the following type which also have a metaphorical constituent:

meat-axe reduction - "pauschale Kürzung",

yellow-dog contract - "Arbeitsvertrag, der den Beitritt zur Gewerkschaft verbietet",

blind-alley job/dead-end job - "Beruf ohne Zukunft", bait and switch technique - "Lockvogeltaktik", beggar-my-neighbour policy - "Leistungsbilanzüberschußpolitik".

The phrase pop-and-mom store "Tante-Emma-Laden" may be associated with jocular connotations, and is colloquial.

The dictionary presents a number of metaphorical verb phrases which also correspond in English and German on the stylistic level, such as.

to jam on the credit brake - "Kreditbremse anziehen", to work on the knocker - "Klinken putzen",

to eke out a living - "sich kümmerlich durchschlagen".

Quite a number of simplex and phrasal verbs listed by the author have derogatory connotations, such as to sweep off - "Geld einstreichen", and to sap - 
"jemanden fertigmachen".

Colloquial and/or slangy connotations are also shared by several expressions consisting of an adjective plus noun in English and a compound in German. The metaphorical element is present in the source and the target language. Examples for illustration are:

filthy lucre - "schmutziges Geld",
messy job - "Drecksarbeit",
sweated money - "Hungerlohn",
slaughtered price - "Schleuderpreis".

These expressions designate an unpleasant situation or state of affairs by means of an adjective which associates a negative evaluation.

Obviously, derogatory and pejorative connotations seem to abound in those economic words and phrases that have no terminological status, but are colloquial or slangy vogue words used by journalists. Drastic examples of this type also include:

milking - "Ausbeutung eines Unternehmens",

rag business - "Damenbekleidungsindustrie" (women's clothing industry), shopaholic (analogous to workaholic) - "kaufwütig",

frothy market - "nervöser Markt", fledgling recovery - "zögernde Erholung".

To sum up, Theo van Bernem's dictionary is rich in informal economic vocabulary. The author has captured the context-sensitive meaning of the English expression in a more generalised German equivalent. He has included many neologisms. On the whole, the German equivalents are on a similar stylistic level, even though the author does not offer usage labels.

A remarkable advantage of this dictionary is that it has been updated in several recent editions, and that university students have made a considerable contribution by their project work in gathering current vocabulary from American economic journals.

\subsubsection{Wilhelm Schäfer (20006): Wirtschaftswörterbuch. Band I Englisch- Deutsch. Band II Deutsch-Englisch.}

The authors have included English and German expressions on the informal (colloquial) and slang levels of usage and accordingly apply style markers/usage labels, such as infml. (informal), sl. (slang). Their dictionary is introduced by a linguistic chapter entitled "Bemerkungen zur Lexikographie".

Examples of economic vocabulary on the nonneutral level (words and phrases that have expressive or stylistic connotations) are: 
Kredithai (Fin., infml.) - "loan shark" (Fin. stands for Finance), Kredithahn zudrehen (Fin., infml.) - "to cut off credit to",

Kreditbremse ziehen (infml.) - "to clamp down on credits"; (sl) - "to jam on the credit brake".

\subsubsection{Hans-Jürgen Behr and Walther Bachmann (1973): Technik-Wörterbuch Geowissenschaften. Englisch-Deutsch.}

This dictionary was a joint project of a subject expert and a language specialist (who was an LSP teacher and a technical translator and interpreter) at the Mining Academy of Freiberg, Saxony. The authors collected colloquial and slangy vocabulary used in the field of mineral deposits ("Lagenstättenkunde"), such as colourful metaphors and monosyllabic, clipped words. These are summarised under the umbrella term "slang" and identified in the dictionary entry by the usage label sl. Unfortunately, the German equivalent is not marked in the same fashion. Thus, the German native speaker and translator into his/her mother tongue will be faced with a stylistically neutral expression which is constituted by a compound or by a descriptive phrase. It may happen that the German equivalent does not have the same stylistic (slangy) connotations as the English word or phrase. In this case, the dictionary authors have placed emphasis on conceptual equivalence rather than on stylistic adequacy.

The slangy vocabulary is interspersed with animal metaphors. To give a few examples:

ant mound (sl.) - "Schlammvulkan",

camel back (sl.) - "Ausbucklungen des Firstgesteins",

doghouse (sl.) - "Bohrmeisterbude" (drilling workers' shed; Bude is colloquial in German too),

bat (sl.) - "Kohlenschiefer", cat dirt (sl.) - 1. "Kohle mit Pyrit"; 2. "harter, feuerfester Ton", cow-dung bomb (not specified, but probably slang) - "Schlackenkuchen", cowstone (sl.) - "Grünsandsteinblock", lamb and slack (sl.) - "minderwertige Kohle", toadstone (sl.) - "Melaphyr, Basaltporphyr".

Quite a number of slang words are used to designate workers in the oil-drilling field. Thus, roughneck (sl.) and roustabout (sl.) refer to a "Bohrarbeiter" (a drilling and milling worker in mining), and mud smeller (sl.) to an "Erdölgeologe" (a geologist who does the probing).

There are also numerous slang words that designate minerals, structures of rocks, and divisions inside a mine or pit. To quote a few examples:

barnyard (sl.) - "interglazialer Bodenhorizont", balmstone (sl.) - "hangendes Gestein", 
kackle-meckle (sl.) - "sehr reines Bleierz in Cornwall", storm stone (sl.) - "Donnerkeil, Belemnit".

Another example not labelled as slang, but probably informal (descriptive, jocular or pejorative), is the expression niggerheads "Kugelkohle".

To sum up, the slang vocabulary used in geophysics, geotectonics, geotechnology and mining shares the fields of metaphors (that is, names of animals, parts of the human body) with other subject domains and also the vocabulary on the neutral stylistic level.

\subsubsection{Peter Axel Schmitt (1992): PONS Fachwörterbuch der KFZ-Technik. Englisch-Deutsch. Deutsch-Englisch.}

The author of the dictionary of automotive engineering, Peter A. Schmitt, has systematically included colloquial vocabulary which was gathered by a considerable number of technical translators (postgraduate students and professional translators at the University of Mainz-Germersheim). Having worked for many years in several car-producing companies as a technical translator and handbook writer and being familiar with the factory floor, the author unites the expertise of a subject specialist and that of a language expert.

The head word in the dictionary as the key entry has been chosen as the preferred term. It is the standardised designation and does not have any expressive or stylistic connotations. Synonyms are of subordinate importance, but they are adequately described.

The author has developed a scale of usage levels which include pragmatic information such as rare, coll (colloquial), form (formal), mot (motoring), obs (obsolete), poet (poetic), ppsc (popular science), pract (practical), press (press media usage), elevated and norm (normalized). This type of highly specified information is a remarkable advantage over other comparable dictionaries in the same field. The detailed pragmatic information complements the semantic information which contains a definition or an explanation of the term. The author's intention is to offer the dictionary user computerised subject-specific, linguistic and pragmatic data in each lexical entry. Apart from a subject field indicator, the definition or explanation of the lexical unit and the German equivalent(s), there are references to synonymy, related terms, regional varieties of usage (BE (British English), AE (American English), Aus (Australian English)) and separate compounds. A typical example of this kind of a lexical entry is the term convertible. The entry has the following key word display:

convertible, conv (mot) (conv stands for convertible)

topless automobile coll press

open-air automobile press

ragtop coll

droptop coll

- offenes Auto n ( $n$ stands for Neutrum) 
- Cabrio ugs (umgangssprachlich)

- Oben-ohne-Auto ugs press

- Cabriolet (2) obs form geh (gehoben)

- Kabriolet $\mathrm{n}$ obs form

Schmitt's dictionary is both descriptive and stipulative, and, by providing pragmatic information on the technical term in the source and target language, has many advantages over those LSP dictionaries which neglect or deliberately exclude colloquial and slangy words and phrases.

\section{Results and Discussion}

The presentation of a few select monolingual and bilingual dictionaries of different subject areas has shown that informal, colloquial, jargon and slang words have a justified place in an LSP dictionary because they also have firm footing in current LSP usage. Such words and phrases are a realistic picture of the discourse community of a special domain and its subfields. Moreover, they have sociolinguistic implications regarding the language user on a particular social stratum. In this respect, LSP dictionaries should collect, systematize and explain the word-stock (words and phrases of a language for special purposes) in all its dimensions of a functional variety of usage or a trade dialect. In the light of a vertical stratification of LSP communication, the vocabulary listed in an LSP dictionary should exceed that of pure terminology and nomenclature. The problem for the lexicographer, however, lies in collecting informal and slang terms. As a rule, statistically representative groups of informants are hardly available. Thus, the source of slang terms in economics are slipshod articles written by American journalists in newspapers and magazines. On the other hand, the geologist working on an oilfield abroad will become familiar with English slang words in the process of learning by doing. And, in a different context, the authors of legal dictionaries may have consultations with persons who are in charge of prison methods and familiar with the behaviour and the language of prisoners.

In the last instance, jargon and slang words will continue to enrich all sorts of technical vocabularies. An LSP lexicographer must, nevertheless, bear in mind that informal and slang words may be short-lived and be ousted by other colourful vocabulary often coined by the younger generation of special language users.

\section{Literature (select bibliography)}

Behr, Hans-Jürgen and Walther Bachmann. 1973. Technik-Wörterbuch Geowissenschaften. EnglischDeutsch. Edited by Adolf Watznauer. Berlin: VEB Verlag Technik.

Collin, P.H. 1994' [1986]. Dictionary of Law. Teddington, Middlesex: Peter Collin Publishing Ltd. 
Fink, Hermann. 19996. EconoTerms. A Glossary of Economic Terms. With a Supplement EconoSlang In collaboration with Paul Schons and Wolfgang Rothfritz. Sprachen und Kulturen München/Wien: R. Oldenbourg Verlag.

Fluck, Hans-Rüdiger. 19965. Fachsprachen. Einführung und Bibliographie. Tübingen: A. Francke Verlag.

Gläser, Rosemarie. 1978. Fachstile des Englischen. Leipzig: VEB Verlag Enzyklopädie.

Messinger, Heinz und der Langenscheidt-Redaktion. 19916. Langenscheidts Grosswörterbuch der englischen und deutschen Sprache. Der kleine Muret-Sanders. Deutsch-Englisch. Berlin/Munich: Langenscheidt.

Messinger, Heinz, Helmut Willmann und der Langenscheidt-Redaktion. 1991s. Langenscheidts Grosswörterbuch der englischen und deutschen Sprache. Der kleine Muret-Sanders. DeutschEnglisch. Berlin/Munich: Langenscheidt.

Romain, Alfred, Hans Anton Bader and B. Sharon Byrd. 20005. Wörterbuch der Rechts- und Wirtschaftssprache. Teil 1. Englisch-Deutsch. München: C.H. Beck'sche Verlagsbuchhandlung/ Basel/Mainz/Wien: Helbing und Lichtenhahn.

Sager, Juan S., David Dungworth and Peter F. McDonald. 1980. English Special Languages. Principles and Practice in Science and Technology. Wiesbaden: Oscar Brandstetter Verlag KG.

Schäfer, Wilhelm. 20006. Wirtschaftswörterbuch. Band I Englisch-Deutsch. Band II Deutsch-Englisch. Established by Wilhelm Schäfer†, edited by Michael Schäfer in collaboration with Gabriele Strake-Behrendt. München: Verlag Franz Vahlen.

Schmitt, Peter Axel. 1992. PONS Fachwörterbuch der KFZ-Technik. Englisch-Deutsch. Deutsch-Englisch. Stuttgart/Dresden: Ernst Klett Verlag für Wissen und Bildung.

Van Bernem, Theodor. 19943. Wirtschaftsenglisch-Wörterbuch. Englisch-Deutsch. Deutsch-Englisch. München/Wien: R. Oldenbourg Verlag. 